\title{
Perceptual differences in offer quality between Western Australian rock lobster exporters and Japanese rock lobster importers ${ }^{1}$
}

\begin{abstract}
An empirical examination of the perceived differences in offer quality between Western Australian rock lobster exporters and their respective Japanese importers reveals that consistent quality, a willingness to provide market information and a willingness to meet importers' immediate needs were the most important variables influencing an importer's decision to purchase. While both importers and exporters agreed that delivering consistent quality was the most important variable, exporters ranked competitive price much higher. While the emphasis on price is indicative of a declining market, Western Australian exporters need to give greater consideration towards adding more value to their product offer by providing continuous product support, more timely market information and responding better to importers immediate needs, rather than competing on price against lower cost producers.
\end{abstract}

Key words: offer quality, supplier selection, Japan

\section{Introduction}

Australia is the world's largest producer and exporter of rock lobster. Seven Panulirus and Jasus rock lobster species are found in Australian waters of which four species, the Western Rock Lobster (P. cygnus), Tropical Rock Lobster ( $P$. ornatus), the Southern Rock Lobster ( $J$. novaehollandiae) and Eastern Rock Lobster (J. verreauxi) are commercially fished (Brown and Phillips, 1994).

Widely distributed between Shark Bay and east of Cape Leeuwin, the Western Rock Lobster industry is regarded as the second largest commercial rock lobster fishery in the world, with the catch averaging 10,575 tonnes per annum (Brown and Phillips, 1994). The Western Rock Lobster industry accounts for approximately $70 \%$ of the total Australian rock lobster catch and with sales approaching \$300 million per annum, is the single most valuable fishery in Australia. In 1997/98, almost 12,250 tonnes of rock lobsters were exported from Australia, worth an estimated \$424 million (Australian Commodity Exports, 1998). The major export destinations were to Taiwan (34\%), Japan (29\%) and Hong Kong (23\%).

Japan is Australia's most important seafood market. However, the consumption of seafood is declining and the market is becoming increasingly price competitive. Furthermore, in the current economic climate, greater numbers of Japanese consumers are becoming uneasy about their

\footnotetext{
${ }^{1}$ Batt, Peter J. and Ryuta Morooka (2003), Perceptual differences in offer quality between Western Australian rock lobster exporters and Japanese rock lobster importers, Supply Chain Management: an International Journal (in press)
} 
economic wellbeing. Consumer spending has declined and more consumers are demanding better value for their money (Williams and Taya, 1999).

In Japan, rock lobsters have traditionally been used for decorating tables at weddings and other important celebrations (JETRO, 1997). They are generally considered good luck, for the more the tail is curved and the back is bent, the longer one's life. However, more recently, the demand for wedding receptions has decreased as couples move towards more simplistic, less expensive weddings and prices have correspondingly decreased.

As the domestic production of rock lobsters in Japan approaches only 1,200 tonnes per annum (JETRO, 1997), the demand is met primarily from imports (83\%). In 1998, Japan imported almost 11,900 tonnes of rock lobsters (Ministry of Agriculture, Forestry and Fisheries, 1999). While Australia continues to dominate the Japanese import market for rock lobster (39\%), imports from Australia have gradually declined in proportion to the total quantity of rock lobsters imported. Similarly, the average value of Australian rock lobster imports has declined, indicative of both a decline in the demand for the product and increasing price competition from lower cost producers in Cuba and South Africa. Unable to compete on price, Australian rock lobster exporters must investigate alternative means of improving the offer quality and differentiating the product in the market.

\section{Offer quality}

Industrial buying behavior is purposively directed towards the achievement of rational economic goals, where the major objective is to find least cost solutions which best satisfy functional criteria. Quality, price and the ability to deliver are generally regarded as the most important criteria by which organizational buyers evaluate potential suppliers (Cunningham and White, 1973; Lehmann and O’Shaughnessy, 1974; Dempsey, 1978; Wilson, 1994). Where there is no difficulty in accurately specifying the exact nature of the product and there are several reliable suppliers in the market, a buyer can simply choose that supplier who offers the lowest price from among all those who fulfill the functional requirements (Hakansson, Johanson and Wootz, 1977).

However, where a number of alternative suppliers have equaled one another in terms of quality, delivery and price, various attributes such as the supplier's reputation, financial position, communication and attitude towards the buyer may become decisive (Dempsey, 1978). Kotler and Armstrong (1999) suggest that suppliers who are the most capable of offering quality products and services, competitive prices, reliable delivery, ethical corporate behavior and honest communication are most likely to be rewarded as preferred suppliers. However, other decision variables may include service capabilities, technical support, geographic location and performance history. Monczka, Trent and Handfield (1998) add financial capability and stability as key decision variables.

Hutt and Speh (1995) suggest that when industrial buyers purchase a product, they purchase not only a package of benefits derived from the physical product features, but also a bundle of services attached to the product. While the exact meaning of the term service varies with the nature of the product and the requirements of the buying organization, service may encompass such things as just-in-time delivery, the provision of technical assistance and support, 
innovations and adaptations, credit arrangements, support for special needs, or advance notice of impending price changes or shortages in delivery. Leenders and Fearon (1993) suggest that preferred suppliers take the initiative of suggesting better ways to service customers and attempt to find new ways of developing products and services which will allow customers to perform their activities more economically.

In the international marketing environment, while there are many similarities among the supplier selection criteria used by purchasing managers in different countries, significant differences may exist as well. Lehmann and O’Shaughnessy (1974) describe the differences in supplier selection criteria between US and European purchasing managers. Ford (1984) shows how distance influences supplier selection in Europe. Mummalaneni, Dubas and Chao (1996) present the relative importance of various supplier selection attributes in China, while Ghymm and Jacobs (1993) and Hirakubo and Kublin (1998) discuss the relative importance of various supplier selection criteria in Japan.

\section{Japanese buying behavior}

The Japanese purchaser-supplier relationship is typically described as cooperative, interdependent, integrated and often exclusive (Hirakubo and Kublin, 1998). Such relationships focus on maximizing the efficiency of the entire value chain, where the principal goal of the partnership is to increase quality while minimizing the total value-added costs that both the supplier and the purchaser incur (Dyer and Ouchi, 1993). Typically, both parties work jointly to solve problems and to expand overall profitability, rather than seeking how best to divide the profit. While various efficiencies may be gained from having fewer suppliers, Nishiguchi and Brookfield (1997) attribute lower transactional costs to the prevalence of moral trading relationships which facilitate mutual investments and a broader flow of information. Hofstede (1991) finds that Japan is an extremely risk-averse society with a very high level of uncertainty avoidance. Japanese companies minimize the risk of making an incorrect decision by purchasing from well known suppliers, staying with current suppliers or selecting suppliers with experience (Hirakubo and Kublin, 1998). In evaluating a new supplier, purchasing staff will customarily visit the supplier's production facility and examine, in depth, their financial and management soundness. Even so, most Japanese companies will usually maintain at least two suppliers, encouraging and facilitating competition between suppliers to help them improve their production techniques and achieve total quality, cost and delivery (Dyer and Ouchi, 1993).

While the majority of the literature relates to manufacturing, and, in particular, the automobile industry, very little attention has been given to the selection criteria Japanese companies use in making their decision to purchase food and agricultural commodities. To fill that void, this paper seeks to identify the criteria Japanese seafood importers consider most important in their decision to purchase rock lobsters.

Given the cultural distance between Japanese buyers and their Western Australian (WA) rock lobster suppliers, the second part of this paper sought to explore the extent to which WA exporters were able to perceive the requirements of Japanese rock lobster importers, and, in turn, how well WA rock lobster exporters were able to satisfy those requirements. 


\section{Methodology}

In order to obtain information from Japanese rock lobster importers and WA rock lobster exporters, two structured questionnaires were developed; one for the Japanese importers and one for the WA exporters. Initially, the questionnaires sought to obtain information about the scale of the business, the quantities of rock lobsters traded and the form in which the product was traded (live or whole frozen). Respondents were then asked to indicate the extent to which they agreed or disagreed with 14 measures of supplier selection criteria on a scale of 1 (not at all important) to 6 (very important). Scales were developed from previous research reported by Cunningham and White (1973), Lehmann and O’Shaughnessy (1974), Hakansson and Wootz (1975), Dempsey (1978) and McQuiston (1989).

A list of Japanese rock lobster importers was obtained from the Japan Marine Products Importers Association in Tokyo. For the 25 rock lobster importers in the Association, data was collected by conducting personal interviews with import managers. However, in making the initial request for an interview, companies that had not purchased rock lobsters from WA were excluded. Furthermore, because of cost and time constraints, the survey was conducted only in the Kanto and Kansai regions. Japanese importers were first asked to rate the importance of the 14 supplier selection criteria. They were then asked to rate how well WA rock lobster exporters met those same criteria. The interviews were conducted in Japanese by the second author.

From the list provided by the WA Rock Lobster Development Association, all eleven members were approached for a personal interview. WA rock lobster exporters were asked how important they believed the same 14 criteria were to their Japanese importers and, in turn, how well they believed WA rock lobster exporters were able to satisfy those criteria.

In order to overcome some of the difficulties associated with gaining a response from several Japanese importers, WA rock lobster exporters were asked to reveal the names of the companies they dealt with in Japan. Whenever the respondent indicated that they dealt with a Japanese company from whom a response had not been obtained, a copy of the questionnaire was left with the exporter who then forwarded the questionnaire to their customer with a covering letter. To preserve anonymity, the responses were returned directly by facsimile to the researchers.

In order to determine whether there was any significant difference in the rank order of the means, Scheffe's Test was applied. To then ascertain if there was any significant difference in the importance of the supplier selection criteria between what Japanese importers ideally wanted, what WA exporters thought their customers wanted and how well WA exporters met each of these same criteria, the t test was employed.

\section{Results and discussion}

\section{Sample validation}

From the 25 Japanese rock lobster importers, responses were received from ten companies. Given the research methodology, while the response rate was only $40 \%$, it was found that the quantity of product imported by these ten companies exceeded 9,700 tonnes, approximately $80 \%$ 
of the total imports of rock lobsters into Japan (MAFF, 1999). The total quantity of live rock lobsters imported by respondents was 3,915 tonnes (74\% of the total) and 7,963 tonnes of frozen rock lobsters (85\% of the total). Therefore, although the response rate was low, there was evidence to suggest that the major Japanese rock lobster importers had been interviewed.

The larger companies (4) imported between 2,000-3,999 tonnes of seafood per annum; the medium size importers (3) between 1,000-1,999 tonnes; and the smaller importers (3) less than 1,000 tonnes. Most respondents (8) imported whole frozen rock lobster in quantities ranging from 200-2,700 tonnes per annum, but only 4 respondents currently imported live rock lobster, generally in much smaller quantities (350-1,300 tonnes per annum).

Of the 11 WA rock lobster exporters, 8 exporters responded to the survey (73\%). Collectively, the total quantity of Western Rock Lobsters exported by respondents was 9,042 tonnes. With total exports approaching 9,980 tonnes (Kevin, 1998), despite the small sample size, the respondents were responsible for more than $90 \%$ of the total quantity exported.

The smaller companies (4) exported less than 1,000 tonnes of seafood per annum; the medium size companies (2) between 1,000-1,999 tonnes; and the larger companies (2) between 2,0003,999 tonnes. All eight companies were currently exporting both live rock lobsters (150-645 tonnes per annum) and whole frozen rock lobsters (100-1,630 tonnes per annum).

\section{Perceptual differences in offer quality}

Consistent quality was the most important attribute Japanese seafood importers sought from foreign rock lobster suppliers (Table 1).

Table 1. Relative importance of supplier selection criteria between Japanese rock lobster importers and Western Australian rock lobster exporters.

\begin{tabular}{|l|c|c|c|c|c|c|}
\hline \multirow{2}{*}{} & \multicolumn{2}{|c|}{$\begin{array}{c}\text { Japanese } \\
\text { importers }\end{array}$} & \multicolumn{2}{c|}{ WA exporters } & \multirow{2}{*}{ Sig. } \\
\cline { 2 - 5 } & Mean & SD & Mean & SD & & \\
\hline Consistent quality & 5.70 & 0.48 & 5.50 & 0.53 & 0.823 & 0.424 \\
\hline Provides market information & 5.56 & 0.53 & 4.00 & 0.76 & 4.864 & $\mathbf{0 . 0 0 0}$ \\
\hline Willingness to meet immediate needs & 5.50 & 0.53 & 4.50 & 1.07 & 2.421 & $\mathbf{0 . 0 3 7}$ \\
\hline Good reputation & 5.30 & 0.67 & 5.13 & 0.35 & 0.708 & 0.491 \\
\hline Continuous product support & 5.30 & 0.48 & 4.38 & 1.06 & 2.284 & $\mathbf{0 . 0 4 7}$ \\
\hline Frequent communication & 5.00 & 0.67 & 5.00 & 0.76 & 0.000 & 1.000 \\
\hline Technically capable & 4.90 & 1.52 & 4.50 & 0.93 & 0.687 & 0.503 \\
\hline Enable importers to visit exporters & 4.80 & 0.79 & 4.25 & 1.04 & 1.281 & 0.218 \\
\hline Competitive price & 4.40 & 1.43 & 5.25 & 0.89 & -1.545 & 0.143 \\
\hline Strong customer base & 4.40 & 1.17 & 3.38 & 0.74 & 2.253 & $\mathbf{0 . 0 3 9}$ \\
\hline Financially strong & 4.30 & 0.95 & 3.75 & 0.89 & 1.268 & 0.224 \\
\hline Favorable terms of repayment & 4.20 & 1.03 & 3.88 & 1.25 & 0.593 & 0.563 \\
\hline Frequent visits with importers & 4.10 & 1.52 & 4.13 & 0.83 & -0.042 & 0.967 \\
\hline Offer other seafood products & 2.80 & 1.14 & 2.25 & 0.89 & 1.154 & 0.265 \\
\hline
\end{tabular}

where 1 is "not at all important" and 6 is "very important" 
Fortuitously, it was also perceived to be the most important attribute WA rock lobster exporters believed Japanese importers required from their suppliers.

While no significant difference in either the Japanese importers ranking of the importance of the selection criteria or the WA exporters perceived ranking of the importers needs could be ascertained, several significant differences were detected between the responses given by importers and exporters.

Most notable was the much greater importance Japanese importers' placed on the provision of market information. Whereas Japanese importers ranked willingness to provide market information as the second most important variable, WA rock lobster exporters ranked willingness to provide market information tenth out of 14 variables.

In a commodity market where there are many suppliers of homogeneous products that are readily substitutable, information about the quantities available and prices are readily exchanged (Fisher, 1997). However, since the rock lobster industry in WA is based on "wild capture", it is seldom possible to know in advance what proportion of the catch will fall within specified size ranges, nor is it always possible to catch sufficient product because of adverse weather at sea, although most WA exporters maintain some reserves of live product in purpose built tanks. Because of this uncertainty and the need for Japanese importers to fulfill the needs of their downstream customers, they need to know in advance of any impeding product shortage or variation in supply. This is particularly important since most Japanese importers endeavor to reduce costs by maintaining minimal inventories and replenishing stock levels often in small quantities.

Consequently, Japanese importers expect their preferred suppliers to be able to respond quickly to their immediate needs. Most often, this arises from an unforeseen increase in the demand. As in most industrial markets, importers respond to the derived demand from customers and consumers. In many cases, an increase in demand can be anticipated, based on the occurrence of festivals or occasions such as New Year. However, while there is a pronounced spring wedding season, importers cannot predict with any certainty how many couples may choose to marry on any particular day. While importers endeavor to hold some reserve stock, lobsters are expensive and particularly for the live product, losses must be anticipated which will significantly reduce the importers profit margin. Fortuitously, WA exporters also recognized the inherent variability in the market and the need to respond to the importers immediate needs.

In equal eighth position, Japanese importers indicated that a strong customer base was significantly more important than WA rock lobster exporters believed it to be. Alpert et al. (1997) suggests that in Japan, size is a surrogate for stability. Because of the long-term nature of business-to-business relationships in Japan, an importer's willingness to purchase depends upon expectations about the success and duration of the relationship. Small suppliers are perceived as being more likely to fail. Furthermore, small suppliers may not have sufficient resources to maintain a long-term relationship with a potential customer. However, from the WA exporters perspective, a strong customer base was perceived to be the second least important variable in their customer's choice of potential exchange partner. 
Perhaps in response to what is perceived to be a diminishing market and the intense price competition from lower cost producers and other WA rock lobster exporters, exporters rated a competitive price as being the second most important variable in the importers decision to purchase. Importers, however, rated competitive price in equal eighth position. The strong importance attached to price by the exporters is indicative of a more traditional short-term adversarial approach to purchasing. In a commodity market where products are often undifferentiated and there is intense competition from substitute products, from the exporters perspective, WA exporters will understandably feel the increased pressure on prices. However, it is more likely that exporters are reacting, as one would expect, to the Japanese practice of "kyosou koubai", where two or more suppliers are put under intense competitive pressure (Rexha and Miyamoto, 2000). While often assumed to be competitive bidding, the principle is however vastly different; suppliers with similar capabilities are stimulated and encouraged to improve their price and quality through harmonious and constructive rivalry. As suppliers become more competent and more competitive, importers are able to build competitive advantage.

Nevertheless, it is evident from the high standard deviation, that price is much more important for some importers than it is for others. While the small sample size precludes us from making any statistically significant findings, price was of greater importance for those importers who handled larger quantities of the frozen product, since there were more alternative suppliers. By maintaining multiple suppliers from different countries, importers are in a better position to capture any financial benefits that may arise from fluctuations in exchange rates. On the other hand, since the importation of live product is highly specialized and the product commands a significantly higher price in the end market, the market was much less sensitive to price, although, due to reduced consumer demand, there was significant downward pressure on prices. Consequently, what we have observed, even in a declining market, is that quality remains the most important variable in the importers decision to purchase. Price is not the driving force (Lambert, Adams and Emmelhainz, 1997), so much so, that any attempt to compete on price alone may incur additional costs because of inferior quality, unreliable delivery, limited quantities and inadequate communication (Simpson, Siguaw and White, 2002). Such may also be indicative of the shift away from adversarial arms-length transactions towards more cooperative long-term buyer-seller relationships (Wilson, 1994). In such situations, importers seek to lower costs and improve quality by selecting those suppliers who are most capable of making continuous improvements in products and processes and who are both more willing and able to support the product in the market.

Particularly with the live product, a high level of technical expertise is required to achieve a successful out-turn in the market. In order to reduce losses and to improve profitability, Japanese importers look towards their suppliers for assistance. Since most WA exporters maintain at least some reserves of live product in purpose built tanks and they have repeatedly shown themselves capable of consigning live product to the market, it seems only sensible that Japanese rock lobster importers will seek advice from their trading partners. However, product support also includes new product development, the adaptation of products or packaging to the Japanese market or supporting and servicing the product in the market through such activities as sales promotion. In this regard, the provision of continuous product support was important to all Japanese importers. 


\section{Differences in performance}

Research has shown that to improve and maintain market share, suppliers must endeavor to match their performance on various selection criteria to the relative importance the buyer places on those same criteria (Lambert, Adams and Emmelhainz, 1997). Competitive advantage is best gained by performing well on those attributes considered important to the buyers, while over performing on unimportant criteria is an inefficient use of resources.

While there is much debate on the various methodologies one can use to evaluate supplier performance, Ennew, Reed and Binks (1993) suggest that a comparison of the mean scores of the importance of various attributes and the supplier's perceived performance in delivering against those same attributes provides a straightforward measure of how well a particular supplier meets customers needs.

Fortuitously, while Japanese importers rated the performance of WA exporters marginally lower on their ability to deliver consistent quality product, there was no statistically significant difference (Table 2).

Table 2. Extent to which Western Australian rock lobster exporters met Japanese rock lobster importers expectations.

\begin{tabular}{|l|c|c|c|c|c|c|}
\hline \multirow{2}{*}{} & \multicolumn{2}{|c|}{$\begin{array}{c}\text { Japanese } \\
\text { importers } \\
\text { expectations }\end{array}$} & \multicolumn{2}{c|}{$\begin{array}{c}\text { WA exporters } \\
\text { performance }\end{array}$} & t & Sig \\
\cline { 2 - 6 } & Mean & SD & Mean & SD & \\
\hline Consistent quality & 5.70 & 0.48 & 5.20 & 0.92 & 1.627 & 0.138 \\
\hline Provides market information & 5.56 & 0.53 & 4.89 & 0.78 & 2.828 & $\mathbf{0 . 0 2 2}$ \\
\hline Willingness to meet immediate needs & 5.50 & 0.53 & 4.50 & 0.97 & 3.354 & $\mathbf{0 . 0 0 8}$ \\
\hline Good reputation & 5.30 & 0.67 & 5.00 & 0.67 & 1.964 & 0.081 \\
\hline Continuous product support & 5.30 & 0.48 & 4.30 & 0.67 & 3.873 & $\mathbf{0 . 0 0 4}$ \\
\hline Frequent communication & 5.00 & 0.67 & 5.10 & 0.57 & -0.287 & 0.780 \\
\hline Technical capability & 4.90 & 1.52 & 4.70 & 0.48 & 0.375 & 0.716 \\
\hline Enable importers to visit exporters & 4.80 & 0.79 & 4.10 & 1.10 & 1.655 & 0.132 \\
\hline Competitive price & 4.40 & 1.43 & 4.20 & 0.63 & 0.429 & 0.678 \\
\hline Strong customer base & 4.40 & 1.17 & 4.30 & 0.82 & 0.318 & 0.758 \\
\hline Financial strength & 4.30 & 0.95 & 4.30 & 0.67 & 0.000 & 1.000 \\
\hline Favorable terms of repayment & 4.20 & 1.03 & 4.00 & 0.94 & 0.557 & 0.591 \\
\hline Frequent visits with importers & 4.10 & 1.52 & 3.90 & 1.10 & 0.318 & 0.758 \\
\hline Offer other seafood products & 2.80 & 1.14 & 2.40 & 1.26 & 0.768 & 0.462 \\
\hline
\end{tabular}

Since we are dealing with a natural, wild capture product, some variation in the physical appearance of the product or its ability to remain alive for a sustained period is inevitable and will persist, irrespective of any quality assurance system. However, in their willingness to provide market information, to meet importers immediate needs and to support the product in the market, Japanese importers considered the performance of WA Rock Lobster exporters to be significantly below what they ideally required from a preferred supplier. 
In Japan, where the majority of trade is conducted on the basis of long-term relationships, it was abundantly clear that importers expected more market information to be exchanged. This was surprising for the WA rock lobster industry is heavily regulated. All exporters are aware of the size of the catch and distribution of sizes, but it is apparent that such information was not being conveyed to importers.

The inability of WA rock lobster exporters to meet the importers' immediate needs is largely dependent upon two variables; (i) the availability of flights from Australia; and, (ii) the availability of the product. With limited airfreight services from Perth, it is often difficult for exporters to procure freight space at short notice. Similarly, with regard to the frozen product, the minimum quantity that an exporter can realistically consider shipping is one container, and then, their ability to ship will depend upon the shipping schedule. However, more importantly, the WA rock lobster industry is based on "wild capture", and thus it is impossible to know in advance what proportion of the catch will fall within specified size ranges or whether it will be possible to catch sufficient product.

The other area where significant improvement is required is in providing Japanese importers with continuous product support. While Japanese firms have become particularly adept at managing those linkages that lower the firm's handling costs and reduce the required level of inventory, they have also embarked upon more collaborative long-term buyer seller relationships to facilitate greater research and development and the provision of improved after-sales service (Nishiguchi and Brookfield, 1997: Sako, 1992). With their efforts focused primarily on the pricequality relationship, WA exporters are perceived to be less willing to make long-term investments to support their customers.

While Japanese rock lobster importers indicated that a strong customer base was significantly more important than WA rock lobster exporters believed it to be, it was apparent that most Japanese importers believed that their suppliers in WA were sufficiently large to meet their current and anticipated needs. It was also abundantly clear that most Japanese seafood importers looked towards WA primarily as a source of rock lobsters; there was no desire expressed to import other seafood products or to extend the range of product offered.

Since rock lobsters are only available from WA from mid November until late June, for Japanese importers to maintain a continuous supply of (live) product to the market, they will, by necessity, need to switch their purchases among a number of preferred suppliers, depending upon their respective supply periods. Such switching behavior is not at all uncommon in the fresh produce industry and is in itself, largely responsible for much of the global trade in perishable products (Batt, 2000). However, it may also mean that unless there is a significant difference in the quality of alternative products, the baseline price will be established by the least cost producer (Thein and Batt, 1999). Since buyers have been found to place more emphasis on price, quality and delivery in multiple sourcing situations (Swift, 1995), it is entirely understandable that WA exporters should place so much attention on price.

One other issue emerges, which despite the lack of statistical significance, has an important strategic implication for WA rock lobster exporters. While WA rock lobster exporters often make numerous personal visits to the market, usually at the beginning of each season, given the high costs of conducting business in Japan, there may be more cost efficient ways of building 
and maintaining relationships with Japanese importers. In particular, most Japanese importers suggested that exporters seemed reluctant to facilitate or encourage them to visit their operations in WA. Since it is accepted business practice for executives to visit, even relocate to a supplier's production facility for a short period of time (Dyer and Ouchi, 1993), WA rock lobster exporters may not only find it less expensive, but may also achieve a much greater and longer lasting benefit by accommodating their Japanese buyers in Australia.

\section{Managerial implications}

Consistent quality, the willingness to provide market information, to meet importers' immediate needs and willingness to continuously support the product in the market were found to be the most important variables influencing a Japanese seafood importer's choice of supplier. In all four areas, WA rock lobster exporters need to improve performance. Because of the current decline in demand and intense price competition between lower cost producers and intense rivalry between WA rock lobster exporters, from the exporters' perspective, price competition was deemed to be much more important.

However, there is increasing evidence in business-to-business markets that the importance of price as a supplier selection criterion is decreasing in importance (Wilson, 1994; Simpson, Siguaw and White, 2002). In the pursuit of lower costs, quality is emerging as the single most important issue. While Japanese seafood importers will continue to ensure that the product itself meets some minimal quality standard, suppliers have the potential to either positively or negatively affect the importers inventories, product costs and delivery times, which will have a direct influence on their perceived level of satisfaction. In order to remain competitive, WA rock lobster exporters should concentrate on quality issues, especially the ability to meet customer order requirements, logistics and distribution and timeliness. More emphasis should be placed on understanding and responding to customers changing needs, especially in mutually examining opportunities to support the product in the market through perhaps adapting the packaging to meet customers needs, developing new innovative products or simply promoting the product in the market. Most fundamental however, is the need to improve communication and to ensure that Japanese importers are kept fully informed of any variation in the supply that may affect their ability to meet the needs of downstream customers.

\section{Acknowledgements}

The authors acknowledge the constructive comments provided by the two anonymous reviewers to the earlier manuscript.

\section{References}

Alpert, F., Kamins, M., Sakano, T., Onzo, N. and Graham, J. (1997), “Retail Buyer Decisionmaking in Japan: what US Sellers Need to Know”, International Business Review, Vol 6 No. 2, pp. 91-112. 
Australian Commodity Exports (1998), Australian Bureau of Agricultural and Resource Economics, Commonwealth of Australia, Canberra.

Batt, P.J. (2000), "Strategic Lessons to Emerge from an Analysis of Selected Flower Export Nations”, Journal of International Food and Agribusiness Marketing, Vol 11 No. 3, pp. 41-73.

Brown, R.S. and Phillips, B.F. (1994), The current status of Australia's rock lobster fisheries, in Spiny Lobster Management, Blackwell Scientific Publications. Cambridge.

Cunningham, M.T. and White, J.G. (1973), “The Determinants of Choice of Supplier”, European Journal of Marketing, Vol 7, pp. 189-202.

Dempsey, W.A. (1978), “Vendor Selection and the Buying Process”, Industrial Marketing Management, Vol 7, pp. 257-267.

Dyer, J.H and Ouchi, W.G. (1993). “Japanese-style Partnerships: Giving Companies a Competitive Edge”, Sloan Management Review, Fall, pp. 51-63.

Ennew, C.T., Reed, G.V. and Binks, M.R. (1993), "Importance-Performance Analysis and the Measurement of Service Quality”, European Journal of Marketing, Vol 27 No. 2, pp. 59-70.

Fisher, M.L. (1997), “What is the right supply chain for your product?” Harvard Business Review, Vol 75 No. 2, pp. 105-116.

Ford, D. (1984), “Buyer/Seller Relationships in International Industrial Markets”, Industrial Marketing Management, Vol 13, pp. 101-112.

Ghymm, K. and Jacobs, L.W. (1993), “Import Purchasing Decision Behaviour: An Empirical Study of Japanese Import Managers”, International Marketing Review, Vol 10 No. 4, pp. 4-11.

Hakansson, H. and Wootz, B. (1975), "Supplier Selection in an International Environment - An Experimental Study”, Journal of Marketing Research, Vol 12 February, pp. 46-51.

Hakansson, H., Johanson, J. and Wootz, B. (1977), "Influence Tactics in Buyer-Seller Processes”, Industrial Marketing Management, Vol 5, pp. 319-332.

Hirakubo, N. and Kublin, M. (1998), “The Relative Importance of Supplier Selection Criteria: The Case of Electronic Components Procurement in Japan”, International Journal of Purchasing and Materials Management, Spring, pp. 19-24.

Hofstede, G. (1991), Cultures and Organisations - Software of the Mind. McGraw-Hill. London.

Hutt, M.D. and Speh T.W. (1995), Business Marketing Management. A Strategic View of Industrial and Organisational Markets. Fifth Edition. Dryden Press.

Japan External Trade Research Organisation (JETRO)(1997). The Japanese Market for Shrimp and Prawn. International Communication Department. Tokyo. 
Kevin, D. (1998), Western Rock Lobster Management. Options and Issues, Fisheries Management Paper No. 113. Fisheries Western Australia. Perth.

Kotler, P. and Armstrong, G. (1999), Principles of Marketing. International Edition. 8th Edition. Prentice Hall.

Lambert, D.M., Adams, R.J. and Emmelhainz, M.A. (1997), "Supplier Selection Criteria in the Healthcare Industry: A Comparison of Importance and Performance”, International Journal of Purchasing and Materials Management, Winter, 16-22.

Leenders, M.R. and Fearon, H.E. (1993), Purchasing and Materials Management. Tenth Edition. Irwin.

Lehmann, D.R. and O’Shaughnessy, J. (1974), “Differences in Attribute Importance for Different Industrial Products”, Journal of Marketing, Vol 38 April, pp. 36-42.

McQuiston, D.H. (1989), “Novelty, Complexity and Importance as Causal Determinants of Industrial Buyer Behaviour”, Journal of Marketing, Vol 53 No. 2, pp. 66-79.

Ministry of Agriculture, Fisheries and Forestry (1999), The $74^{\text {th }}$ Statistical Yearbook of the Ministry of Agriculture, Fisheries and Forestry, Association of Agriculture and Forestry Statistics. Tokyo.

Monczka, R., R. Trent and Handfield, R. (1998), Purchasing and Supply Chain Management. ITP South Western College Publishing.

Mummalaneni, V., Dubas, K.M. and Chao, C. (1996), “Chinese Purchasing Managers Preferences and Trade-off's in Supplier Selection and Performance Evaluation”, Industrial Marketing Management, Vol 25, pp. 115-124.

Nishiguchi, T. and Brookfield, J. (1997), “The Evolution of Japanese Subcontracting”, Sloan Management Review, Fall, pp. 89-101.

Rexha, N. and Miyamoto, T. (2000), "Relationship-building supplier behaviors for winning customer trust. New insights from case research with nine leading Japanese manufacturers", Advances in International Marketing, Supplement 1, pp. 77-94.

Sako, M. (1992), Prices, quality and trust: inter-firm relations in Britain and Japan. Cambridge University Press. UK.

Simpson, P.M., Siguaw, J.A. and White, S.C (2002), "Measuring the Performance of Suppliers: An Analysis of Evaluation Processes”, Journal of Supply Chain Management, Winter, pp. 29-41.

Swift, C.O. (1995), "Preferences for single sourcing and supplier selection criteria”, Journal of Business Research, Vol 32, pp. 105-111. 
Thein, V. and Batt, P.J. (2000), Examining Asian attitudes to Australian horticultural products in Singapore, Malaysia and Hong Kong, Horticultural Research and Development Corporation. Report No. HG99019.

Williams, S.C. and Taya, K. (1999), "Prospects for the Japanese seafood market in the late 1990’s: Implications for Australian exporters”, Australian Agribusiness Review, Vol 7, Paper No 5. [on-line] www. agribusiness.asn.au/agribusinessreview/99JapaneseFish.htm

Wilson, E.J. (1994), “The Relative Importance of Supplier Selection Criteria: A Review and Update”, International Journal of Purchasing and Materials Management, Summer, pp. 35-41. 